\title{
Raman and infrared spectroscopic characterization of the phosphate mineral paravauxite $\mathrm{Fe}^{2+} \mathrm{Al}_{2}\left(\mathrm{PO}_{4}\right)_{2}(\mathrm{OH})_{2} \cdot 8 \mathrm{H}_{2} \mathrm{O}$
}

\section{Ray L. Frost ${ }^{\mathrm{a}, *}$, Ricardo Scholz ${ }^{\mathrm{b}}$, Andrés Lópes ${ }^{\mathrm{a}}$, Yunfei Xi ${ }^{\mathrm{a}}$, Željka Žigovečki Gobac ${ }^{\mathrm{c}}$, Laura Frota Campos Horta ${ }^{b}$}

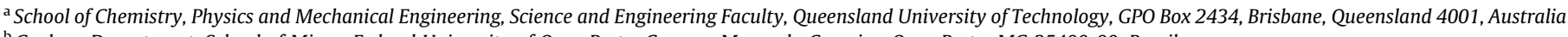

${ }^{\mathrm{b}}$ Geology Department, School of Mines, Federal University of Ouro Preto, Campus Morro do Cruzeiro, Ouro Preto, MG 35400-00, Brazil

' Institute of Mineralogy and Petrography, Department of Geology, Faculty of Science, University of Zagreb, Horvatovac 95, 10000 Zagreb, Croatia

\section{H I G H L I G H T S}

- Paravauxite is a rare phosphate mineral of formula $\mathrm{Fe}^{2+} \mathrm{Al}_{2}\left(\mathrm{PO}_{4}\right)_{2}(\mathrm{OH})_{2} \cdot 8 \mathrm{H}_{2} \mathrm{O}$.

- Chemically, it is closely related to its basic namesake vauxite.

- Another chemically closely related mineral is metavauxite a dimorph of paravauxite.

- We have analysed this mineral using EDX analyses.

- The mineral has been studied by vibrational spectroscopy.

\section{A R T I C L E I N F O}

\section{Article history:}

Received 17 June 2013

Received in revised form 15 July 2013

Accepted 22 July 2013

Available online 2 August 2013

\section{Keywords:}

Paravauxite

Phosphate

Raman spectroscopy

Infrared spectroscopy
G R A P H I C A L A B S T R A C T

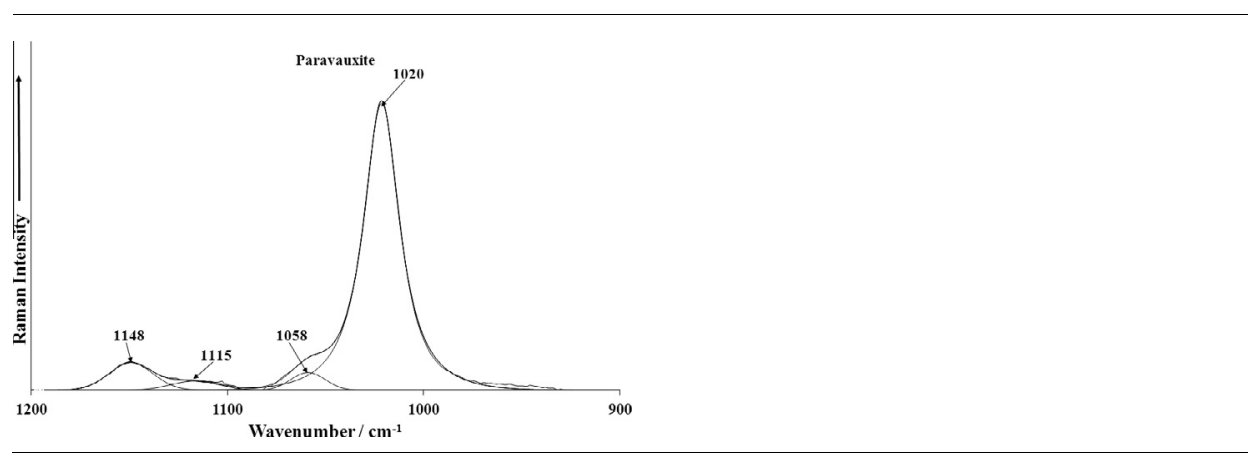

\begin{abstract}
A B S T R A C T
We have undertaken a vibrational spectroscopic study of paravauxite the Siglo XX mine, Bustillo Province, northern of Potosí department, Bolivia. This mine is important source for rare and unusual secondary phosphate minerals and is the type locality for a number of rare phosphates such as vauxite, sigloite, metavauxite and for jeanbandyite. The chemical formula of the studied sample was determined as $\mathrm{Fe}_{0.95}^{2+},\left(\mathrm{Al}_{0.07}\right)_{\Sigma 1.02}(\mathrm{Al})_{2.09}\left(\mathrm{PO}_{4}\right)_{1.97}(\mathrm{OH})_{1.98} \cdot 7.90\left(\mathrm{H}_{2} \mathrm{O}\right)$.

The Raman spectrum is dominated by an intense Raman band at $1020 \mathrm{~cm}^{-1}$ assigned to the $\mathrm{PO}_{4}^{3-} v_{1}$ symmetric stretching mode. Low intensity Raman bands found at 1058,1115 and $1148 \mathrm{~cm}^{-1}$ are assigned to the $\mathrm{PO}_{4}^{3-} v_{3}$ antisymmetric stretching vibrations. Raman bands of paravauxite at 537, 570, 609 and $643 \mathrm{~cm}^{-1}$ are assigned to the $v_{4} \mathrm{PO}_{4}^{3-}$ bending modes whilst the Raman bands at 393 and $420 \mathrm{~cm}^{-1}$ are due to the $v_{2} \mathrm{PO}_{4}^{3-}$ bending modes. The Raman spectral profile of paravauxite in the hydroxyl stretching region is broad with component bands resolved at 3086, 3215, 3315, 3421, 3505 and $3648 \mathrm{~cm}^{-1}$. Vibrational spectroscopy enables the assessment of the molecular structure of paravauxite to be undertaken.
\end{abstract}

(c) 2013 Elsevier B.V. All rights reserved.

\section{Introduction}

Paravauxite is a rare phosphate mineral of formula $\mathrm{Fe}^{2+} \mathrm{Al}_{2}(-$ $\left.\mathrm{PO}_{4}\right)_{2}(\mathrm{OH})_{2} \cdot 8 \mathrm{H}_{2} \mathrm{O}$ which occurs in hydrothermal tin veins, and also in complex granite pegmatites [1]. It was discovered as a new

\footnotetext{
* Corresponding author. Tel.: +61 73138 2407; fax: +61 731381804 .

E-mail address: r.frost@qut.edu.au (R.L. Frost).
}

mineral on wavellite crystals at the tin mines of Llallagua, Bolivia [2]. Paravauxite is a triclinic mineral with $a=5.233, b=10.541$, $c=6.962 \AA, \alpha=106.9^{\circ}, \beta=110.8^{\circ}, \gamma=72.1^{\circ}$, space group $P \overline{1}$ and $Z=1$ [3]. Chemically, it is closely related to its basic namesake vauxite [4,5], and appears to be different from vauxite only in the number of water molecules in the structure. Paravauxite has eight water molecules while vauxite has only six in its formula. Another chemically closely related mineral is metavauxite which 
is a dimorph of paravauxite. In this case, the structure of paravauxite is triclinic [3] while the structure of metavauxite [8] is monoclinic in symmetry. Other members of the stewartite mineral group [7], in which paravauxite belongs, are gordonite $\mathrm{MgAl}_{2}(-$ $\left.\mathrm{PO}_{4}\right)_{2}(\mathrm{OH})_{2} \cdot 8 \mathrm{H}_{2} \mathrm{O}$ [8], kastningite $\left(\mathrm{Mn}^{2+}, \mathrm{Fe}^{2+}, \mathrm{Mg}\right) \mathrm{Al}_{2}\left(\mathrm{PO}_{4}\right)_{2}(\mathrm{OH})_{2}$ $\cdot 8 \mathrm{H}_{2} \mathrm{O}[9,10]$, laueite $\mathrm{Mn}^{2+} \mathrm{Fe}_{2}^{3+}\left(\mathrm{PO}_{4}\right)_{2}(\mathrm{OH})_{2} \cdot 8 \mathrm{H}_{2} \mathrm{O}[11,12]$ mangangordonite $\left(\mathrm{Mg}^{2+}, \mathrm{Fe}^{2+}, \mathrm{Mg}\right) \mathrm{Al}_{2}\left(\mathrm{PO}_{4}\right)_{2}(\mathrm{OH})_{2} \cdot 8 \mathrm{H}_{2} \mathrm{O}$ [8,15], sigloite $\mathrm{Fe}^{3+} \mathrm{Al}_{2}\left(\mathrm{PO}_{4}\right)_{2}(\mathrm{OH})_{3} \cdot 7 \mathrm{H}_{2} \mathrm{O}[16,17]$, stewartite $\mathrm{MnFe}_{2}^{3+}\left(\mathrm{PO}_{4}\right)_{2}(\mathrm{OH})_{2}$. $8 \mathrm{H}_{2} \mathrm{O}$ [13] and ushkovite $\mathrm{MgFe}_{2}^{3+}\left(\mathrm{PO}_{4}\right)_{2}(\mathrm{OH})_{2} \cdot 8 \mathrm{H}_{2} \mathrm{O}$ [19-21].

As paravauxite is isostructural with laueite $\mathrm{Mn}^{2+} \mathrm{Fe}_{2}^{3+}\left(\mathrm{PO}_{4}\right)_{2}$ $(\mathrm{OH})_{2} \cdot 8 \mathrm{H}_{2} \mathrm{O}[3,12,14]$, it could be indirectly concluded that the structure of paravauxite is based on an infinite chain of vertexlinked oxygen octahedra, with Al occupying the octahedral centres, the chain oriented parallel to the $c$-axis. Chains are in turn connected to others by $\mathrm{PO}_{4}$ tetrahedra which also bridge through isolated octahedra (with $\mathrm{Fe}^{2+}$ as centres). The laueite structural formula is $\mathrm{Mn}^{2+} \mathrm{Fe}_{2}^{3+}(\mathrm{OH})_{2}\left(\mathrm{PO}_{4}\right)_{2}\left(\mathrm{H}_{2} \mathrm{O}\right)_{6} \cdot 2 \mathrm{H}_{2} \mathrm{O}$ [12], and according to analogy, the paravauxite structural formula is then $\mathrm{Fe}^{2+} \mathrm{Al}_{2}(-$ $\mathrm{OH})_{2}\left(\mathrm{PO}_{4}\right)_{2}\left(\mathrm{H}_{2} \mathrm{O}\right)_{6} \cdot 2 \mathrm{H}_{2} \mathrm{O}$ and the non-octahedrally bonded waters appearing in a cavity left in the structure. In detailed description, in analogy with laueite structure [14], the chains of Al-octahedra decorated by flanking $\mathrm{PO}_{4}^{3-}$ groups (which extend in $c$-direction) meld in the $a$-direction by sharing one quarter of the flanking $\mathrm{PO}_{4}$ vertices with octahedra of adjacent chains to form an $\left[\mathrm{Al}_{2}(-\right.$ $\left.\mathrm{PO}_{4}\right)_{2}(\mathrm{OH})_{2}\left(\mathrm{H}_{2} \mathrm{O}\right)_{2}$ ] sheet. In the resulting sheet, the $\mathrm{PO}_{4}$ tetrahedra are three-connected. There are two distinct octahedra in these sheets, one of which is six-connected within the sheet, and the other of which is only four-connected and has $\left(\mathrm{H}_{2} \mathrm{O}\right)$ at two vertices. From another view, it could be also described that paravauxite sheet is composed of $\left[\mathrm{Al}\left(\mathrm{PO}_{4}\right)_{2} \mathrm{O}_{2}\right]$ chains that are linked by $\left(\mathrm{AlO}_{6}\right)$ octahedra. These sheets stack in the $b$-direction and are linked by $\left(\mathrm{Fe}^{2+} \mathrm{O}_{2} \mathrm{H}_{2} \mathrm{O}_{4}\right.$ octahedra, and by hydrogen bonds involving the interstitial $\left(\mathrm{H}_{2} \mathrm{O}\right)$ groups bonded to $\mathrm{Fe}^{2+}$ and interstitial $\left(\mathrm{H}_{2} \mathrm{O}\right)$ groups held in the structure solely by hydrogen bonds.

Raman spectroscopy has proven most useful for the study of mineral structures. The objective of this research is to report the Raman and infrared spectra of paravauxite and to relate the spectra to the molecular structure of the mineral. The number of paravauxite occurrences is limited. This is the first report of a systematic study of paravauxite from Bolivia.

\section{Experimental}

\section{Samples description and preparation}

The paravauxite sample studied in this work was collected by one of the authors (Scholz) from the Siglo XX mine (also named Siglo Veinte, Catavi or Llallagua), a tin deposit located in the Andes Mountain, Bustillo Province, northern of Potosí department, Bolivia. In the middle of the 20th century Siglo XX was the most productive tin mine in the world. The mine is also an important source for rare and unusual secondary phosphate minerals and is the type locality for a number of rare phosphates such as vauxite, sigloite, metavauxite and for jeanbandyite. The host rock is a conical subvolcanic stock of Tertiary age and the ore deposit is made up of porphyry and porphyry breccia. Llallagua's stock is heavily altered, almost all of the original feldspar in the volcanic rock has been replaced by quartz, sericitic muscovite, clay tourmaline, pyrite and other minerals. The intrusion was sericitized, tourmalinized and silicified before any of the ores were deposited. Prior silicification of the wall rocks prevented the ore forming solutions from penetrating and replacing the porphyry, so the bulk of the ore was deposited in the open shear zones and fissures [22]. The first depositional stage of the veins is represented by quartz, tourmaline, bismuthinite and cassiterite, with minor wolframite and fluorapatite. The various phosphates, most abundantly wavellite, were formed in the final stages of hydrothermal deposition, and were derived mostly from decomposition of primary fluorapatite [22].

In the Siglo XX mine, colorless to light blue paravauxite aggregates of crystals up to $3.0 \mathrm{~mm}$ in length mainly occur in association with eosphorite. Other secondary phosphates such as wavellite, metavauxite, vauxite, crandallite and childrenite also can be found in association. The sample was incorporated to the collection of the Geology Department of the Federal University of Ouro Preto, Minas Gerais, Brazil, with sample code SAB-006B. The sample was gently crushed and the associated minerals were removed under a stereomicroscope Leica MZ4.

\section{Scanning electron microscopy (SEM)}

Experiments and analyses involving electron microscopy were performed in the Center of Microscopy of the Universidade Federal de Minas Gerais, Belo Horizonte, Minas Gerais, Brazil (http:// www.microscopia.ufmg.br).

Paravauxite crystal aggregate was coated with a $5 \mathrm{~nm}$ layer of evaporated Au. Secondary electron and backscattering electron images were obtained using a JEOL JSM-6360LV equipment. Qualitative and semi-quantitative chemical analysis in the EDS mode were performed with a ThermoNORAN spectrometer model Quest and was applied to support the mineral characterization.

\section{Electron probe micro-analysis (EPMA)}

The quantitative chemical analysis of paravauxite single crystals was carried out using EPMA, with a Jeol JXA8900R spectrometer from the Physics Department of the Federal University of Minas Gerais, Belo Horizonte. The sample was embedded in epoxy resin and after polishing, coated with a thin layer of evaporated carbon. The electron probe microanalysis in the WDS (wavelength dispersive spectrometer) mode was obtained at $15 \mathrm{kV}$ accelerating voltage and beam current of $10 \mathrm{nA}$. For each selected element was used the following standards: Fe - magnetite, $\mathrm{Mg}$ - $\mathrm{MgO}, \mathrm{Mn}-$ rhodonite, $\mathrm{P}$ and $\mathrm{Ca}-\mathrm{Ca}_{2} \mathrm{P}_{2} \mathrm{O}_{7}, \mathrm{Al}$ - Corundum, $\mathrm{Na}$ - Albite100 and $\mathrm{F}$ - Fluorite. Chemical formula was calculated on the basis of 18 oxygen atoms.

\section{Raman microprobe spectroscopy}

Crystals of paravauxite were placed on a polished metal surface on the stage of an Olympus BHSM microscope, which is equipped with $10 \times, 20 \times$, and $50 \times$ objectives. The microscope is part of a Renishaw 1000 Raman microscope system, which also includes a monochromator, a filter system and a CCD detector (1024 pixels). The Raman spectra were excited by a Spectra-Physics model 127 He-Ne laser producing highly polarized light at $633 \mathrm{~nm}$ and collected at a nominal resolution of $2 \mathrm{~cm}^{-1}$ and a precision of $\pm 1 \mathrm{~cm}^{-1}$ in the range between 200 and $4000 \mathrm{~cm}^{-1}$. Repeated acquisitions on the crystals using the highest magnification $(50 \times)$ were accumulated to improve the signal to noise ratio of the spectra. Raman Spectra were calibrated using the $520.5 \mathrm{~cm}^{-1}$ line of a silicon wafer. The Raman spectrum of at least 10 crystals was collected to ensure the consistency of the spectra.

A Raman spectrum of paravauxite is given in the supplementary information as Fig. S1. This spectrum was downloaded from the RRUFF data base (http://www.rruff.info/Paravauxite/R040179). Both polarized and depolarized spectra are provided. The mineral sample studied in the RRUFF data base also originated from Mina Siglo XX, Llallagua, Bolivia.

\section{Infrared spectroscopy}

Infrared spectra were obtained using a Nicolet Nexus 870 FTIR spectrometer with a smart endurance single bounce diamond ATR cell. Spectra over the $4000-525 \mathrm{~cm}^{-1}$ range were obtained by the co-addition of 128 scans with a resolution of $4 \mathrm{~cm}^{-1}$ and a mirror velocity of $0.6329 \mathrm{~cm} / \mathrm{s}$. Spectra were co-added to improve 
the signal to noise ratio. The infrared spectra are given in Supplementary information.

Spectral manipulation such as baseline correction/adjustment and smoothing were performed using the Spectracalc software package GRAMS (Galactic Industries Corporation, NH, USA). Band component analysis was undertaken using the Jandel 'Peakfit' software package that enabled the type of fitting function to be selected and allows specific parameters to be fixed or varied accordingly. Band fitting was done using a Lorentzian-Gaussian cross-product function with the minimum number of component bands used for the fitting process. The Gaussian-Lorentzian ratio was maintained at values greater than 0.7 and fitting was undertaken until reproducible results were obtained with squared correlations of $r^{2}$ greater than 0.995 .

\section{Results and discussion}

\section{Chemical characterization}

The SEM image of paravauxite sample studied in this work is shown in Fig. 1. The image shows a paravauxite cleavage fragment with tabular habitus. No other mineral phase or zonation are observed. Qualitative chemical analysis shows $\mathrm{Fe}, \mathrm{P}$ and $\mathrm{Al}$ as the dominant elements (Fig. 2). Quantitative chemical analysis via EMP allowed us to determine the chemical formula of the studied sample that can be written as:

$\left(\mathrm{Fe}_{0.95}^{2+}, \mathrm{Al}_{0.07}\right)_{\Sigma 1.02}(\mathrm{Al})_{2.09}\left(\mathrm{PO}_{4}\right)_{1.97}(\mathrm{OH})_{1.98} \cdot 7.90\left(\mathrm{H}_{2} \mathrm{O}\right)$

\section{Vibrational spectroscopy}

\section{Background}

Interestingly Farmer in his book on the infrared spectra of minerals divided the vibrational spectra of phosphates according to the presence, or absence of water and hydroxyl units in the minerals [23]. In aqueous systems, Raman spectra of phosphate oxyanions show a symmetric stretching mode $\left(v_{1}\right)$ at $938 \mathrm{~cm}^{-1}$, the antisymmetric stretching mode $\left(v_{3}\right)$ at $1017 \mathrm{~cm}^{-1}$, the symmetric bending mode $\left(v_{2}\right)$ at $420 \mathrm{~cm}^{-1}$ and the $v_{4}$ mode at $567 \mathrm{~cm}^{-1}$ [24-26]. Farmer reported the infrared spectra of berlinite $\left(\mathrm{AlPO}_{4}\right)$ with $\mathrm{PO}_{4}$ stretching modes at $1263,1171,1130$ and $1114 \mathrm{~cm}^{-1}$; bending modes at $511,480,451,379$ and $605 \mathrm{~cm}^{-1}$. Al-O modes were found at $750,705,698$ and $648 \mathrm{~cm}^{-1}$. On hydration of the mineral as with variscite $\left(\mathrm{AlPO}_{4} \cdot 2 \mathrm{H}_{2} \mathrm{O}\right), \mathrm{PO}_{4}$ stretching modes were found at $1160,1075,1050$ and $938 \mathrm{~cm}^{-1}$; bending modes at 515,450 and $420 \mathrm{~cm}^{-1}$; in addition $\mathrm{H}_{2} \mathrm{O}$ stretching bands were found at $3588,3110,2945 \mathrm{~cm}^{-1}$. For the mineral augelite $\left(\mathrm{AlPO}_{4}(\mathrm{OH})_{3}\right)$,

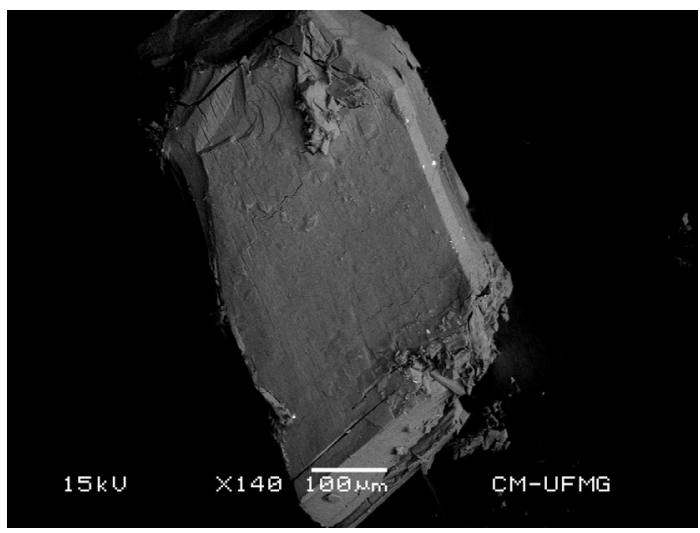

Fig. 1. Backscattered electron image (BSI) of a paravauxite single crystal up to $1.0 \mathrm{~mm}$ in length.

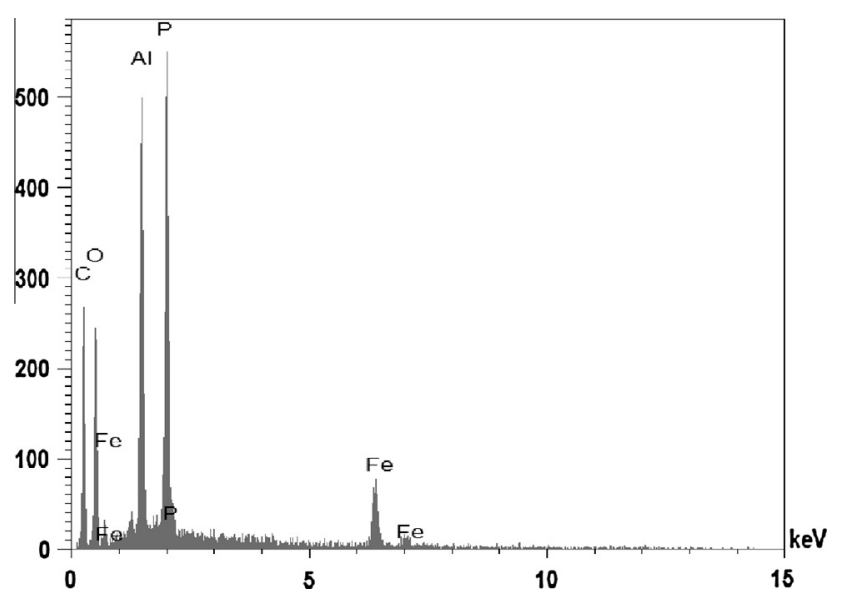

Fig. 2. EDS analysis of paravauxite.

infrared bands were observed at $930\left(v_{1}\right), 438\left(v_{2}\right), 1205,1155$, $1079,1015\left(v_{3}\right)$ and $615,556 \mathrm{~cm}^{-1}\left(v_{4}\right)$. For augelite, $\mathrm{OH}$ stretching modes were not observed.

\section{Spectroscopy}

The Raman spectrum of paravauxite over the $100-4000 \mathrm{~cm}^{-1}$ spectral range is displayed in Fig. 3a. This spectrum shows the position and relative intensity of the Raman bands. There are large parts of the spectrum where no or little intensity is observed. Thus, the spectrum is divided into subsections depending upon the type of vibration being studied. The infrared spectrum of paravauxite over the $600-4000 \mathrm{~cm}^{-1}$ spectral range is displayed in Fig. 3b. As
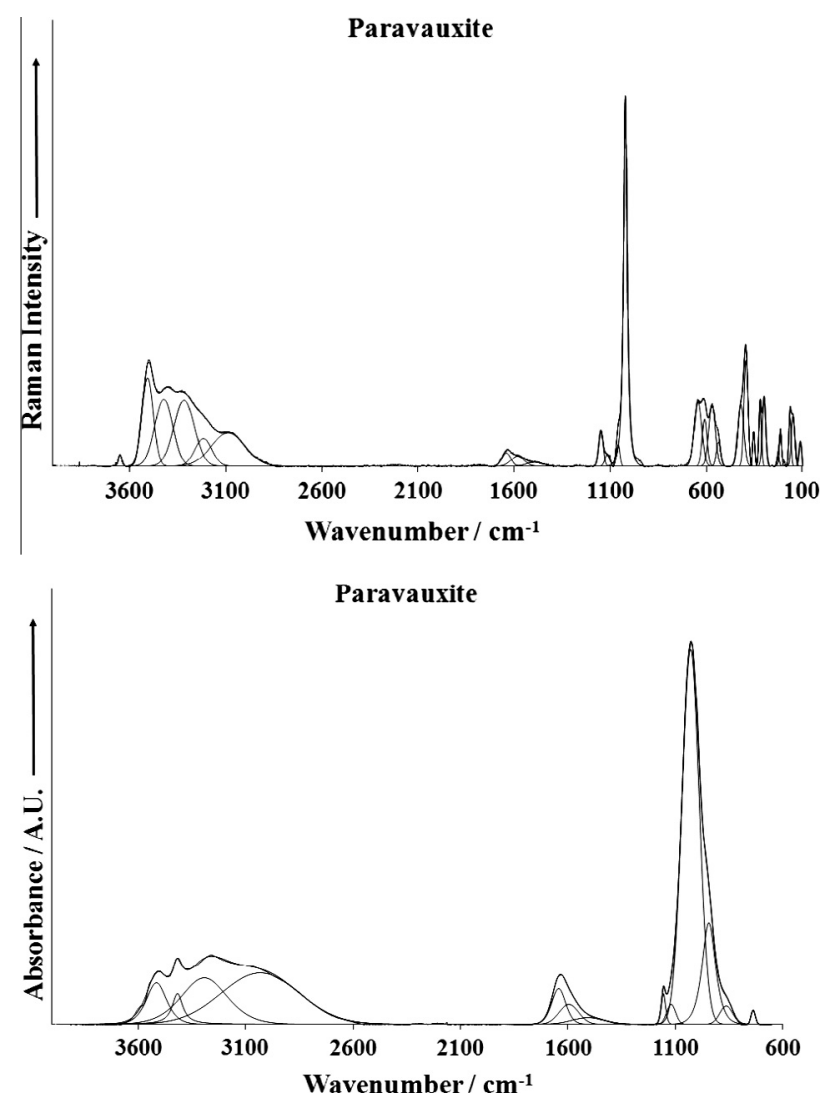

Fig. 3. (a) Raman spectrum of paravauxite over the $100-4000 \mathrm{~cm}^{-1}$ spectral range. (b) Infrared spectrum of paravauxite over the $500-4000 \mathrm{~cm}^{-1}$ spectral range. 
for the Raman spectrum, there are large parts of the spectrum where no intensity is observed and therefore the spectrum is subdivided into sections based upon the type of vibration being examined.

The Raman spectrum of paravauxite over the $900-1200 \mathrm{~cm}^{-1}$ spectral range is reported in Fig. 4a. This spectrum is dominated by an intense Raman band at $1020 \mathrm{~cm}^{-1}$ which is assigned to the $\mathrm{PO}_{4}^{3-} v_{1}$ symmetric stretching mode. Low intensity Raman bands are found at 1058,1115 and $1148 \mathrm{~cm}^{-1}$ and are assigned to the $\mathrm{PO}_{4}^{3-} v_{3}$ antisymmetric stretching vibrations. In the Raman spectrum of paravauxite given in the RRUFF data base, an intense Raman band is observed at $991 \mathrm{~cm}^{-1}$.

The infrared spectrum over the $600-1200 \mathrm{~cm}^{-1}$ spectral range is shown in Fig. 4b. The spectrum shows a broad profile which may be resolved into component bands. Infrared bands are observed at 1027,1117 and $1153 \mathrm{~cm}^{-1}$ and are assigned to the $\mathrm{PO}_{4}^{3-} v_{3}$ antisymmetric stretching vibrational mode. Other infrared bands are found at 735,861 and $942 \mathrm{~cm}^{-1}$. The first band may be attributed to water vibrational mode. The latter two bands are likely due to hydroxyl deformation modes.

A comparison may be made with spectra of other aluminum containing phosphate minerals such as augelite [27] and turquoise [28]. In the Raman spectrum of augelite, an intense band is observed at $1108 \mathrm{~cm}^{-1}$. The band is very sharp with a band width of 7.0. This band is assigned to the $v_{1}$ symmetric stretching mode. Breitinger et al. assigned a band at $1108 \mathrm{~cm}^{-1}$ for synthetic augelites to this mode. The position is in sharp contrast to the value of $930 \mathrm{~cm}^{-1}$ published by Farmer [23]. In the infrared spectrum the band at $1070 \mathrm{~cm}^{-1}$ is assigned to this mode. In the infrared spectrum bands of augelite are observed at 1204, $1171,1142,1102,1070$ and $1016 \mathrm{~cm}^{-1}$. The position of these bands may be compared with those reported by Farmer. Bands
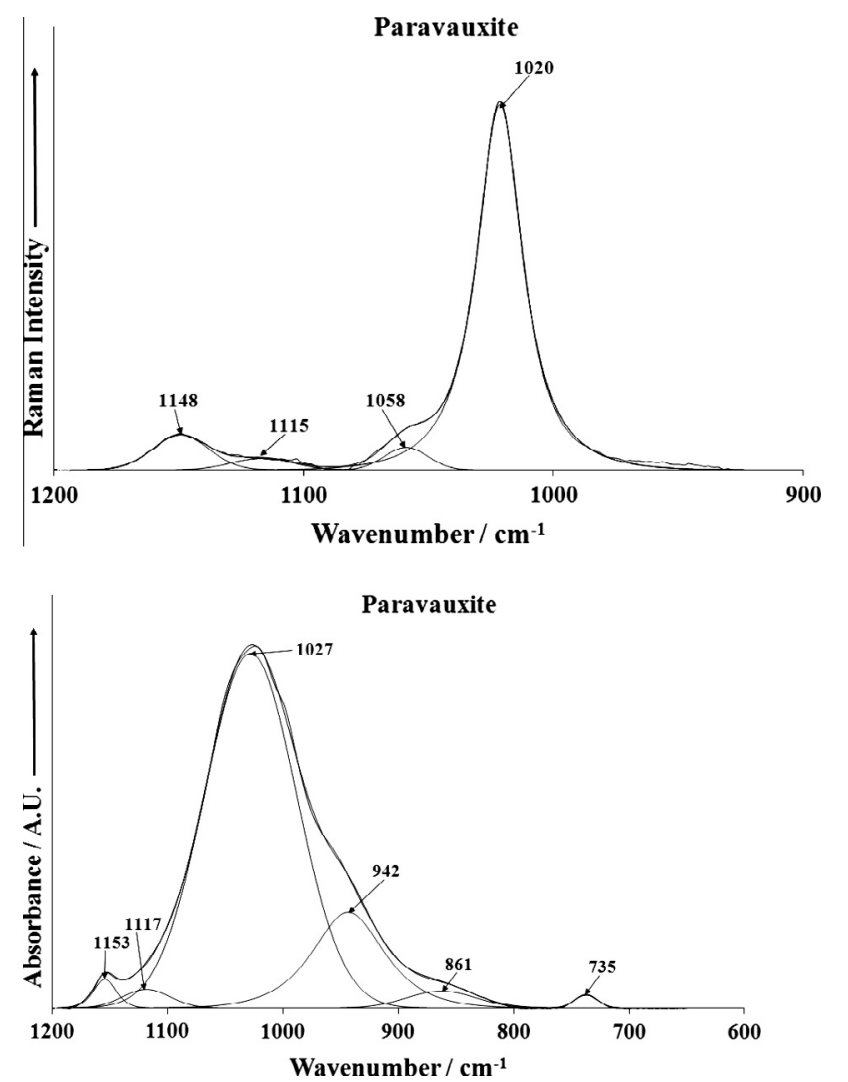

Fig. 4. (a) Raman spectrum of paravauxite over the $800-1400 \mathrm{~cm}^{-1}$ spectral range. (b) Infrared spectrum of paravauxite over the 500 to $1300 \mathrm{~cm}^{-1}$ spectral range. were given as $1205,1155,1079$ and $1015 \mathrm{~cm}^{-1}$. The three higher wavenumber bands $\left(1204,1171,1142 \mathrm{~cm}^{-1}\right)$ are attributed to the $v_{3}$ antisymmetric $\mathrm{PO}_{4}$ stretching vibrations. An intense band is observed at 1160 with a resolved component band at $1136 \mathrm{~cm}^{-1}$ which may be attributed to these vibrational modes. For the turquoise from Senegal, Raman bands are observed at 1182, 1161 and $1104 \mathrm{~cm}^{-1}$. Six bands are predicted from group theory, but are not observed and this is attributed to accidental degeneracy. The two sets of Raman bands from the two independent phosphate units overlap. In the infrared spectrum of turquoise, the three higher wavenumber bands at 1195, 1161 and $1109 \mathrm{~cm}^{-1}$ are ascribed to the $v_{3}$ antisymmetric stretching vibrations.

The Raman spectra of paravauxite in the $300-800 \mathrm{~cm}^{-1}$ and $100-300 \mathrm{~cm}^{-1}$ spectral ranges are shown in Fig. 5a and b. The first spectrum displays a series of overlapping Raman bands. This spectrum may be subdivided into sections. The first section is the 600$800 \mathrm{~cm}^{-1}$ spectral region, the second section is the bands around $500 \mathrm{~cm}^{-1}$ and the third section is the bands between 300 and $400 \mathrm{~cm}^{-1}$. Raman bands at 537, 570, 609 and $643 \mathrm{~cm}^{-1}$ are assigned to the $v_{4} \mathrm{PO}_{4}^{3-}$ bending modes. The Raman bands at 393 and $420 \mathrm{~cm}^{-1}$ are due to the $\mathrm{v}_{2} \mathrm{PO}_{4}^{3-}$ bending modes. In the RRUFF Raman spectrum, a Raman band at $589 \mathrm{~cm}^{-1}$ is shown and is assigned to the $v_{4} \mathrm{PO}_{4}^{3-}$ bending mode (please see Fig. S1). An intense Raman band in the RRUFF spectrum is found at $430 \mathrm{~cm}^{-1}$ and this band is assigned to the $v_{2} \mathrm{PO}_{4}^{3-}$ bending modes.

Raman bands are found at 299, 319 and $353 \mathrm{~cm}^{-1}$ and are attributed to MO vibrations. In the Raman spectrum of paravauxite in the RRUFF data base, Raman bands are observed at 133, 211, 232 and $283 \mathrm{~cm}^{-1}$. Breitinger et al. [29] reported low intensity bands for synthetic augelite at 750 and $530 \mathrm{~cm}^{-1}$ which were assigned to the $v\left(\mathrm{Al}(\mathrm{O} / \mathrm{OH})_{n}\right)$ modes. The Raman spectrum displays a

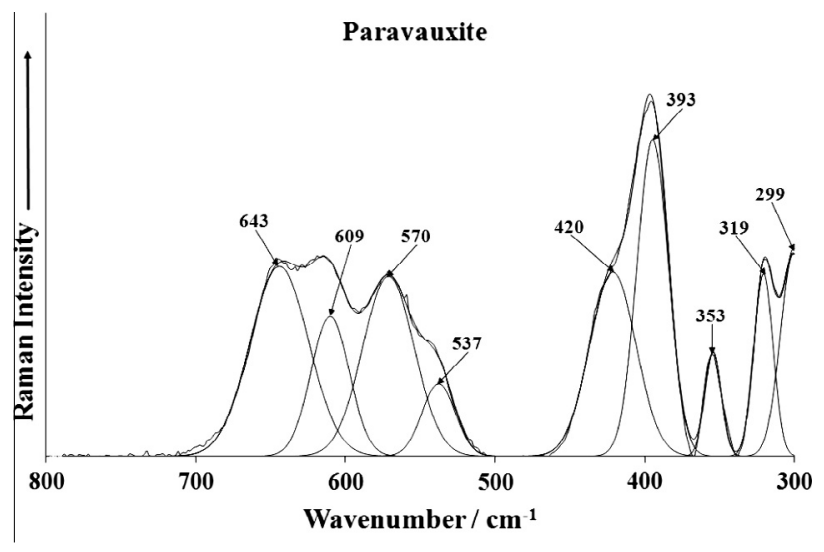

Paravauxite

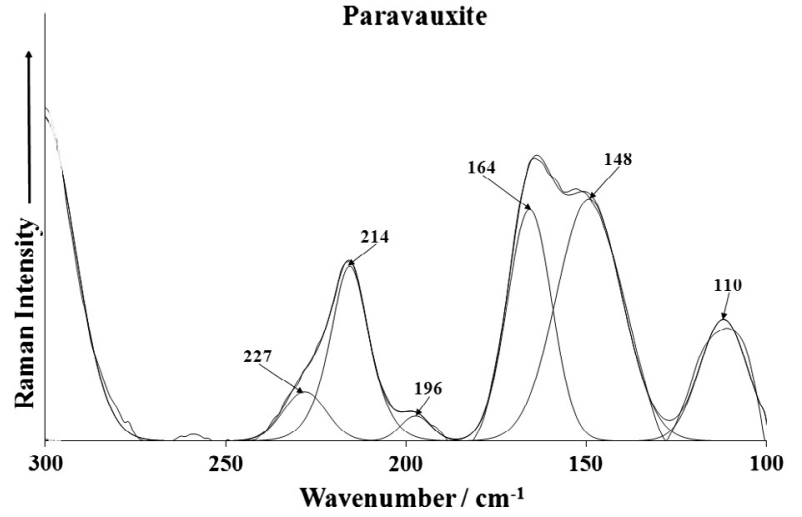

Fig. 5. (a) Raman spectrum of paravauxite over the $300-800 \mathrm{~cm}^{-1}$ spectral range. (b) Raman spectrum of paravauxite over the 100 to $300 \mathrm{~cm}^{-1}$ spectral range. 
number of bands at 110,148,164, 196, 214 and $227 \mathrm{~cm}^{-1}$. These bands are simply described as lattice vibrations.

In the Raman spectrum of augelite, an intense band is observed at $635 \mathrm{~cm}^{-1}$ with component bands at 643 and $615 \mathrm{~cm}^{-1-}$ and are assigned to the $v_{4} \mathrm{PO}_{4}$ mode. In the infrared spectrum of augelite, the band at $645 \mathrm{~cm}^{-1}$ is assigned to this $v_{4} \mathrm{PO}_{4}$ bending mode. In the Raman spectrum bands are observed at 467, 439, 419 and $407 \mathrm{~cm}^{-1}$. These bands are attributed to the $v_{2}$ bending modes of the $\mathrm{PO}_{4}$ units. The Raman spectra of turquoise in the $500-700 \mathrm{~cm}^{-1}$ spectral range are complex with a significant number of overlapping bands. This spectral region is where the $v_{4}$ phosphate bending modes are expected. For turquoise Raman bands are observed at $643,593,570$ and $550 \mathrm{~cm}^{-1}$. The results of FGA show that at least two phosphate bending modes would be expected. With loss of degeneracy this number would be expected to increase. For the turquoise from Senegal, Raman bands are observed at $484,468,439$ and $419 \mathrm{~cm}^{-1}$. For the mineral chalcosiderite two strong bands are observed at 445 and $397 \mathrm{~cm}^{-1}$.

The Raman spectrum of paravauxite over the $2600-3800 \mathrm{~cm}^{-1}$ spectral range is reported in Fig. 6a. The Raman spectral profile is broad with component bands resolved at 3086, 3215, 3315, 3421, 3505 and $3648 \mathrm{~cm}^{-1}$. The chemistry of paravauxite $\mathrm{Fe}^{2+} \mathrm{Al}_{2}(-$ $\left.\mathrm{PO}_{4}\right)_{2}(\mathrm{OH})_{2} \cdot 8 \mathrm{H}_{2} \mathrm{O}$ is such that both water and hydroxyl units are noted. Thus, it would be expected that bands due to both these units would be observed. The ratio of the hydroxyl to water $\mathrm{OHs}$ is $2 / 16$. Thus, the intensity of the water stretching vibrations is expected to be intense. The first 4 bands are assigned to water vibrations. The band at $3648 \mathrm{~cm}^{-1}$ is attributed to the stretching vibration of the hydroxyl units. Bands which may be assigned to water molecules normally occur at lower wavenumbers than the stretching bands of the $\mathrm{OH}$ units. It is noted that this band is absent in the infrared spectrum. The band at $3505 \mathrm{~cm}^{-1}$ could be
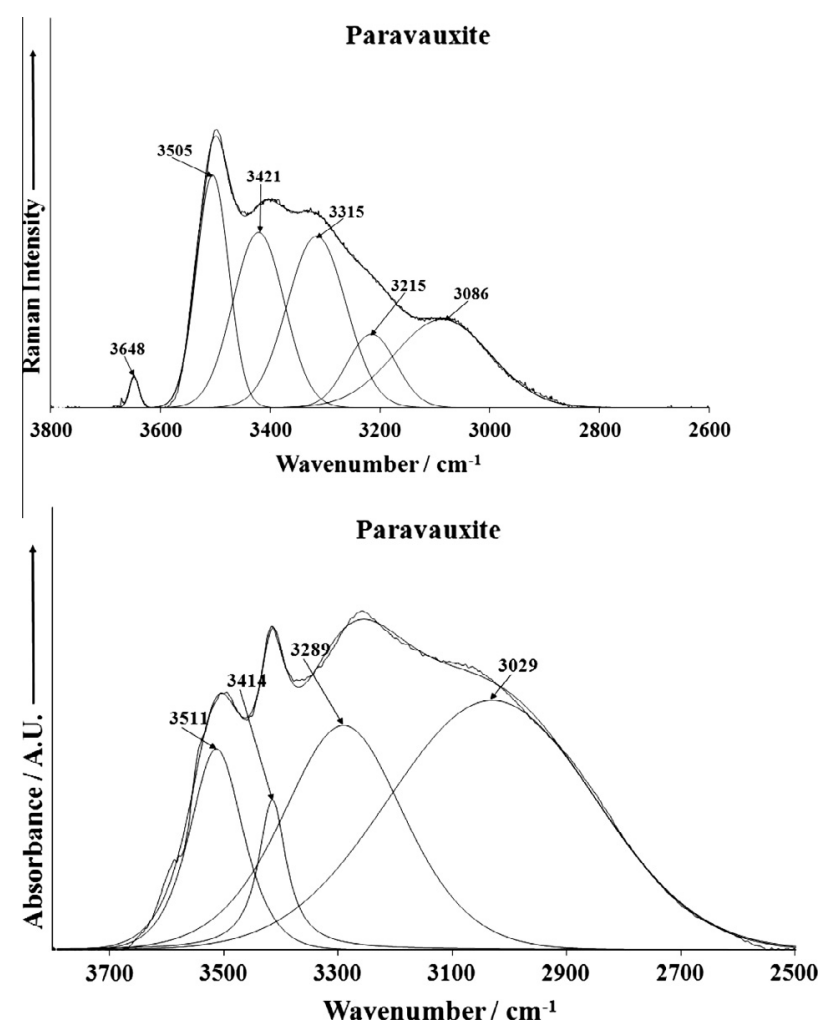

Fig. 6. (a) Raman spectrum of paravauxite over the $2600-4000 \mathrm{~cm}^{-1}$ spectral range. (b) Infrared spectrum of paravauxite over the $2600-4000 \mathrm{~cm}^{-1}$ spectral range.
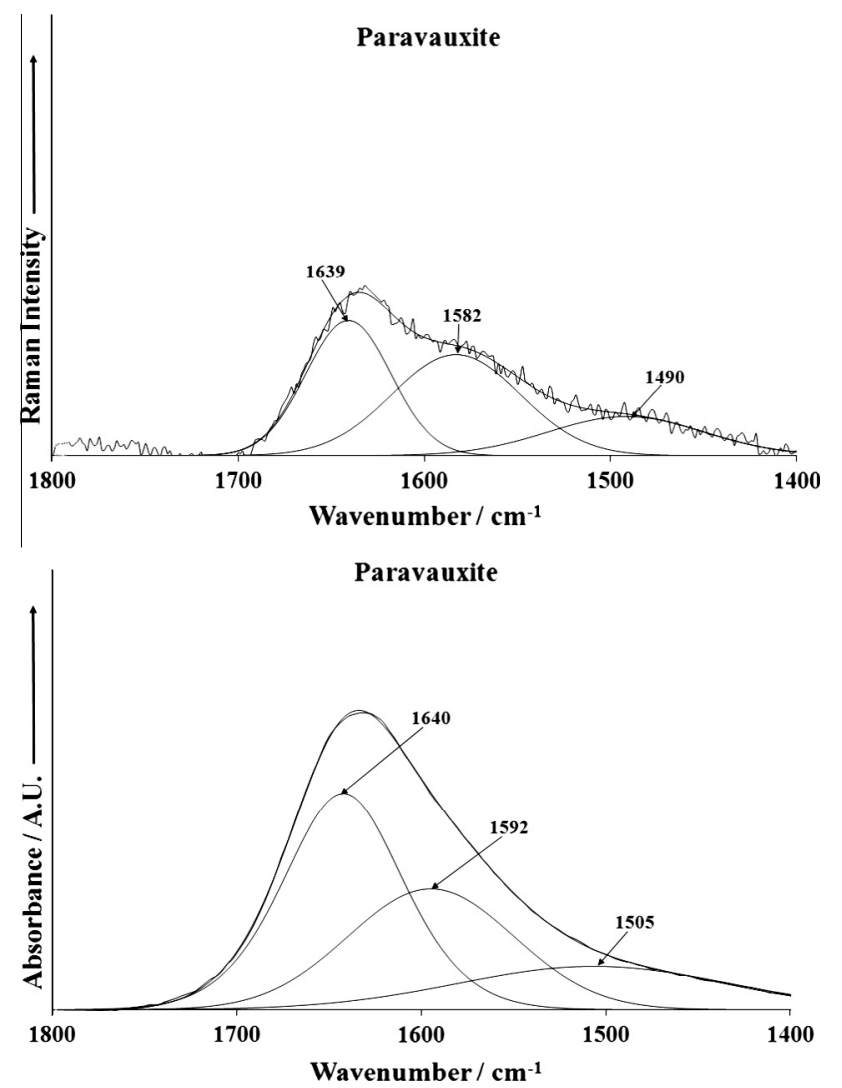

Fig. 7. (a) Raman spectrum of paravauxite over the $1300-1800 \mathrm{~cm}^{-1}$ spectral range. (b) Infrared spectrum of paravauxite over the $1300-1800 \mathrm{~cm}^{-1}$ spectral range.

assigned either way but the assignment to a water stretching vibration is more likely. The infrared spectrum of paravauxite in the $2500-3800 \mathrm{~cm}^{-1}$ spectral range is shown in Fig. 6b. Infrared bands are observed at $3029,3289,3414$ and $3511 \mathrm{~cm}^{-1}$. These infrared bands are attributed to water stretching vibrations. Hydroxyl stretching vibrations are more readily observed in the Raman spectrum and the water stretching bands are very readily observed in the infrared spectrum as water is a very strong infrared absorber.

A comparison may be made with the $\mathrm{OH}$ stretching region of senagalite. Intense very sharp Raman bands are observed at 3505 and $3610 \mathrm{~cm}^{-1}$ with shoulders on the high wavenumber side at 3507 and $3614 \mathrm{~cm}^{-1}$. These bands are attributed to $\mathrm{OH}$ stretching vibrations. The series of low intensity Raman bands are observed at 3099, 3206, 3270, 3339, 3374 and $3429 \mathrm{~cm}^{-1}$ and are assigned to water stretching vibrations. In the infrared spectrum, bands are observed at 3490 and $3609 \mathrm{~cm}^{-1}$ with shoulder bands at 3502 and $3603 \mathrm{~cm}^{-1}$. These bands are ascribed to the stretching vibrations of the hydroxyl units. Intense infrared bands are found at 3061, $3089,3211,3261,3332$ and $3424 \mathrm{~cm}^{-1}$ and are assigned to water stretching vibrations.

The Raman spectrum of paravauxite in the $1400-1800 \mathrm{~cm}^{-1}$ spectral range is illustrated in Fig. 7a; even though the spectrum suffers from a lack of signal, three bands may be resolved ay 1490,1582 and $1639 \mathrm{~cm}^{-1}$. The last band is assigned to the water bending modes. The infrared spectrum over the $1400-1800 \mathrm{~cm}^{-1}$ spectral range is shown in Fig. 7b. Three infrared bands are resolved at 1505,1592 and $1640 \mathrm{~cm}^{-1}$. This last band is ascribed to water bending modes. The other bands may be due to hydroxyl deformation vibrations. 
Table 1

Chemical composition of paravauxite from the Siglo Veinte mine (mean of 10 electron microprobe analyses). $\mathrm{H}_{2} \mathrm{O}$ calculated by stoichiometry.

\begin{tabular}{|c|c|c|c|c|}
\hline Constituent & wt.\% & Range (wt.\%) & Number of atoms & Probe standard \\
\hline $\mathrm{FeO}$ & 14.50 & $15.44-16.55$ & 0.95 & Magnetite \\
\hline $\mathrm{MgO}$ & 0.01 & $0.00-0.03$ & 0.00 & $\mathrm{MgO}$ \\
\hline $\mathrm{Al}_{2} \mathrm{O}_{3}$ & 23.34 & $25.40-26.90$ & 2.16 & $\mathrm{Al}_{2} \mathrm{O}_{3}$ \\
\hline $\mathrm{P}_{2} \mathrm{O}_{5}$ & 29.59 & $32.33-33.60$ & 1.97 & $\mathrm{Ca}_{2} \mathrm{P}_{2} \mathrm{O}_{7}$ \\
\hline $\mathrm{MnO}$ & 0.11 & $0.04-0.30$ & 0.01 & Rhodonite \\
\hline $\mathrm{CaO}$ & 0.00 & $0.03-0.07$ & 0.00 & $\mathrm{Ca}_{2} \mathrm{P}_{2} \mathrm{O}_{7}$ \\
\hline $\mathrm{Na}_{2} \mathrm{O}$ & 0.11 & $0.01-0.14$ & 0.00 & Albite 100 \\
\hline $\mathrm{F}$ & 0.08 & $0.00-0.13$ & 0.00 & Fluorite \\
\hline $\mathrm{H}_{2} \mathrm{O}$ & 33.93 & Calculated by stoichiometry & $\mathrm{H}_{2} \mathrm{O}-7.90 \mathrm{OH}-1.98$ & \\
\hline Total & 101.67 & & & \\
\hline
\end{tabular}

\section{Conclusions}

As paravauxite is isostructural with laueite $\mathrm{Mn}^{2+} \mathrm{Fe}_{2}^{3+}$ $\left(\mathrm{PO}_{4}\right)_{2}(\mathrm{OH})_{2} \cdot 8 \mathrm{H}_{2} \mathrm{O}[13]$, it could be indirectly concluded that the structure of paravauxite is based on an infinite chain of vertexlinked oxygen octahedra, with Al occupying the octahedral centres, the chain oriented parallel to the $c$-axis. Chains are in turn connected to others by $\mathrm{PO}_{4}$ tetrahedra which also bridge through isolated octahedra (with $\mathrm{Fe}^{2+}$ as centres). Chemically, paravauxite is closely related to its basic namesake vauxite $[5,6]$, and appears to be different from vauxite only in the number of water molecules in the structure. Paravauxite has eight water molecules while vauxite has only six in its formula.

The paravauxite sample studied in this work is from the type locality, the Siglo XX mine. The chemical formula calculated on the basis of EMP analysis can be written as

$\left(\mathrm{Fe}_{0.95}^{2+}, \mathrm{Al}_{0.07}\right)_{\Sigma 1.02}(\mathrm{Al})_{2.09}\left(\mathrm{PO}_{4}\right)_{1.97}(\mathrm{OH})_{1.98} \cdot 7.90\left(\mathrm{H}_{2} \mathrm{O}\right)$.

A combination of Raman spectroscopy at ambient temperatures complimented with infrared spectroscopy has been used to characterize the phosphate mineral paravauxite. The Raman spectrum is dominated by an intense Raman band at $1020 \mathrm{~cm}^{-1}$ assigned to the $\mathrm{PO}_{4}^{3-} v_{1}$ symmetric stretching mode. Low intensity Raman bands found at 1058,1115 and $1148 \mathrm{~cm}^{-1}$ are assigned to the $\mathrm{PO}_{4}^{3-} \quad v_{3}$ antisymmetric stretching vibrations. Raman bands of paravauxite at 537, 570,609 and $643 \mathrm{~cm}^{-1}$ are assigned to the $v_{4}$ $\mathrm{PO}_{4}^{3-}$ bending modes whilst the Raman bands at 393 and $420 \mathrm{~cm}^{-1}$ are due to the $v_{2} \mathrm{PO}_{4}^{3-}$ bending modes. The Raman spectral profile of paravauxite in the hydroxyl stretching region is broad with component bands resolved at 3086, 3215, 3315, 3421,3505 and $3648 \mathrm{~cm}^{-1}$. Assignment of these bands is somewhat difficult. The bands are assigned to water and hydroxyl unit stretching vibrations (see Table 1 ).

\section{Acknowledgments}

The financial and infra-structure support of the Discipline of Nanotechnology and Molecular Science, Science and Engineering Faculty of the Queensland University of Technology, is gratefully acknowledged. The Australian Research Council (ARC) is thanked for funding the instrumentation. The authors would like to acknowledge the Center of Microscopy at the Universidade Federal de Minas Gerais (http://www.microscopia.ufmg.br) for providing the equipment and technical support for experiments involving electron microscopy. R. Scholz thanks to CNPq - Conselho Nacional de Desenvolvimento Científico e Tecnológico (Grant No. 306287/ 2012-9). Ž. Žigovečki Gobac thanks to Ministry of Science, Education and Sports of the Republic of Croatia, under Grant No. 1190000000-1158. L.F.C. Horta thanks to PET/Geologia/UFOP.

\section{Appendix A. Supplementary material}

Supplementary data associated with this article can be found, in the online version, at http://dx.doi.org/10.1016/j.saa.2013.07.048.

\section{References}

[1] J.W. Anthony, R.A. Bideaux, K.W. Bladh, M.C. Nichols, Arsenates, Phosphates, Vanadates, vol. IV, Mineral Data Publishing, Tucson, 2000.

[2] S.G. Gordon, Science 56 (1922) 50.

[3] W.H. Baur, Neues Jahrb. Min. (1969) 430-433.

[4] S.G. Gordon, Am. Min. 7 (1922) 108.

[5] S.G. Gordon, Proc. Acad. Nat. Sci. Phila. 75 (1923) 261-270.

[6] W.H. Baur, R.R. Rao, Naturwissenschaften 54 (1967) 561.

[7] M.E. Back, J.A. Mandarino, Fleischer's Glossary of Mineral Species, The Mineralogical Record Inc, Tucson, 2008.

[8] P.B. Leavens, A.L. Rheingold, Neues Jahrb. Min. (1988) 265-270.

[9] J. Schlüter, K.-H. Klaska, K. Friese, G. Adiwidjaja, Neues Jahrb. Min. (1999) 4048.

[10] G. Adiwidjaja, K. Friese, K.-H. Klaska, J. Schlüter, Zeit. Krist. 214 (1999) 465468.

[11] H. Strunz, Naturwissenschaften 41 (1954) 256

[12] P.B. Moore, Am. Min. 50 (1965) 1884-1892.

[13] P.B. Moore, Laueite, Neues Jahrb. Min. 123 (1975) 148-159.

[14] D.M.C. Huminicki, F. C. Hawthorne, The crystal chemistry of the phosphate minerals, in: Paul H. Ribbe (Ed.), Reviews in Mineralogy and Geochemistry, Phosphates. Geochemical, geobiological and materials importance. 2002.

[15] P.B. Leavens, J.S. White, G.W. Robinson, J.A. Nelen, Neues Jahrb. Min. (1991) $169-176$.

[16] R.L. Frost, Y. Xi, R. Scholz, F.M. Belotti, M. Candido Filho, J. Mol. Struct. 1033 (2013) 258-264

[17] C.S. Hurlbut Jr., R. Honea, Am. Min. 47 (1962) 1-8.

[19] B.V. Chesnokov, V.A. Vilisov, G.E. Cherepivskaya, M.G. Gorskaya, Zapiski Vsesoyuznogo Mineralogicheskogo Obshchestva 112 (1983) 42-46.

[20] P.J. Dunn, Min. Rec. 16 (1985) 463-464.

[21] M.A. Galliski, F.C. Hawthorne, Can. Min. 40 (2002) 929-937.

[22] J. Hyrsl, A. Petrov, Min. Rec. 37 (2006) 117-162.

[23] V.C. Farmer, Mineralogical Society Monograph 4: The Infrared Spectra of Minerals, London, 1974.

[24] R.L. Frost, W. Martens, P.A. Williams, J.T. Kloprogge, Min. Mag. 66 (2002) 1063 1073.

[25] R.L. Frost, W.N. Martens, T. Kloprogge, P.A. Williams, Neues Jahrb. Min. (2002) 481-496.

[26] R.L. Frost, P.A. Williams, W. Martens, J.T. Kloprogge, P. Leverett, J. Raman Spectrosc. 33 (2002) 260-263.

[27] R.L. Frost, M.L. Weier, J. Mol. Struct. 697 (2004) 207-211.

[28] R.L. Frost, B.J. Reddy, W.N. Martens, M. Weier, J. Mol. Struct. 788 (2006) $224-$ 231.

[29] D.K. Breitinger, J. Mohr, D. Colognesi, S.F. Parker, H. Schukow, R.G. Schwab, J. Mol. Struct. 563-564 (2001) 377-382. 